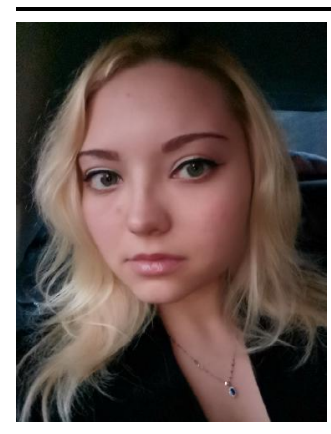

УДК 339.187:63.021.66

https://doi.org/10.47612/978-985-7149-55-1-2020-18-20

Михалина Арнатович, магистр экономических наук, аспирантка Институт системных исследований в АПК НАН Беларуси, г. Минск

\title{
Упаковка как средство \\ обеспечения конкурентоспособности плодоовощной продукции
}

Важной составляющей в решении вопроса обеспечения конкурентоспособности товаров выступает упаковка. Последняя рассматривается как средство сохранения продукта в процессе хранения и транспортировки, а также как маркетинговый инструмент продвижения продукции на рынок. При этом с развитием промышленности и технологий она становится все более совершенной. По данным Всемирной упаковочной организации (WPO), в мире производится 1800 млрд ед. упаковки для продуктов питания и напитков, ежегодно на рынок выводится 275 тыс. ед. новой пищевой упаковки, а оборот мирового рынка, по прогнозам экспертов, к 2020 г. достигнет 1 трлн долл. США [12].

В теории и практике конкурентоспособность товара определяется системой качественных и экономических показателей. По мнению А. Оливье, А. Дайана и Р. Урсе, необходимо при их оценке учитывать: 1) концепцию товара и услуги, на которой базируется деятельность предприятия; 2) качество продукта; 3) цену товара с торговой наценкой; 4) собственные и заемные финансы субъекта; 5) торговые методы продажи; 6) послепродажное обслуживание; 7) внешнюю торговлю организации; 8) предпродажную подготовку товара [1]. В. Гусаков, 3. Ильина, Н. Батова, А. Дурович, Н. Киреенко, А. Пилипук, А. Селезнев, Р. Фатхутдинов предлагают также рассматривать наличие инновационных технологий, обеспеченность высококвалифицированными кадрами, функционирование сбытовой сети [6-9, 11 , $13,15]$. В развитие данных методических подходов вышеуказанные и другие авторы включают в качестве фактора конкурентоспособности расширение маркетинговых инструментов, в том числе и активное использование упаковки [3, 10, 14].

Упаковку рассматривают с точки зрения нормативно-технических, эстетических, психологических и информационных особенностей. В Республике Беларусь в соответствии с ГОСТ 17527-2003 упаковка представляет собой средство (или комплекс средств), обеспечивающее защиту продукции от повреждения и потерь, окружающую среду от загрязнений, а также процесс обращения продукции (транспортирование, хранение, реализация продукции) [5]. В качестве основных ее элементов выступают тара, упаковочные и перевязочные материалы, защитные оболочки. Она выполняет комплекс функций, взаимосвязанных между собой и обеспечивающих реализацию производственных, экономических, потребительских, экологических, социальных, культурных, информационных и других решений. Как показывает практика, покупателям уже необходима упаковка, сохраняющая свежесть и органолептические свойства продуктов, сокращая время их приготовления, а также защищая товар от фальсификации и хищений (рис.).

Для плодоовощной продукции, которая реализуется как в свежем, так и переработанном виде, использование

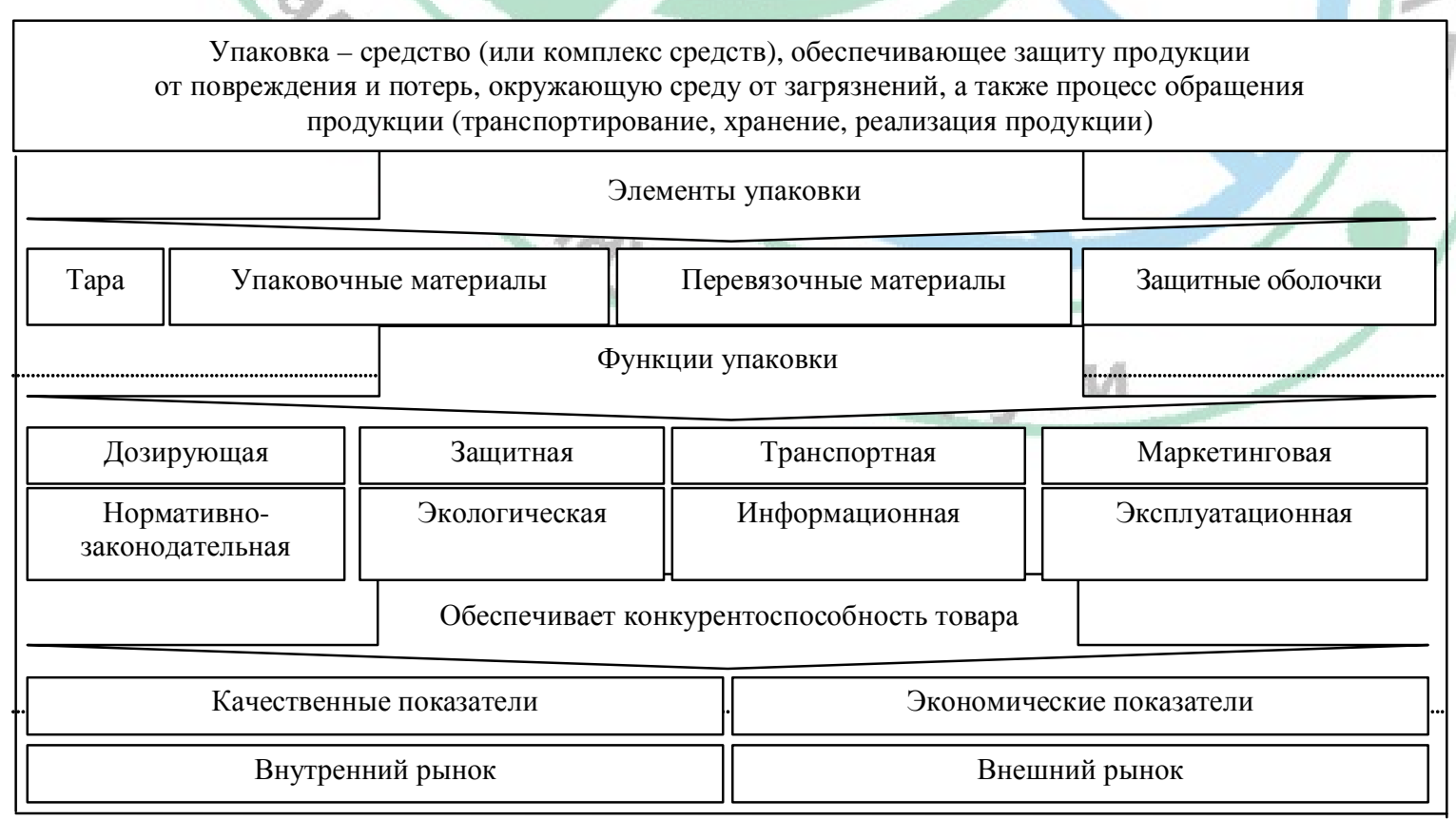

Рис. Понятие, элементы и функции упаковки в системе обеспечения конкурентоспособности товара 
упаковки направлено на сохранение потребительских свойств товара, создание компактного груза для погрузки, выгрузки, складирования, транспортировки, продажи (по весу и объему), содействие продвижению продукции на рынок. Исследования показали, что развитие упаковочной индустрии плодоовощной продукции базируется на международных, региональных и национальных правилах торговли, учитывает специфику товара и особенности формирования рыночного спроса (конечные потребители формируют различия в сегментах возраста, пола, социального статуса). При этом специалисты Продовольственной и сельскохозяйственной организации Объединенных Наций (FAO) отмечают, что в рамках мировой тенденции увеличения потребления свежих плодов и овощей конечный потребитель все больше предъявляет требования к качеству и безопасности, питательной ценности и удобству [12].

Изменение в культуре питания также влияет на современные тенденции в упаковочной индустрии, среди которых выделяются:

- рост объемов потребления свежих плодов и овощей, связанный с усилением тренда здорового питания;

0 - увеличение спроса на подготовленные плоды и овощи (полуфабрикаты), что значительно упрощает процесс приготовления домашних блюд, связанный с растущей занятостью женщин;

- расширение сегментации рынка свежих плодов и овощей за счет их разнообразия и видов упаковки.

К числу мировых тенденций относятся: рост заказов через Интернет, требующий других видов упаковки (менее красочной, более прочной); рост спроса на «умную» упаковку, упаковку с дополненной реальностью, специальные виды упаковки (например, разогревающаяся); вытеснение бумажных этикеток прозрачными полимерными пленками; рост стоимости сырья и ламинатов; внедрение принципов Индустрии 4.0.

В настоящее время существуют различные виды упаковок для плодоовощной продукции, количество которых постоянно расширяется с развитием инновационных технологий. Среди традиционных активно используется транспортная (для перевозки товаров и при оптовой или мелкооптовой продаже) и потребительская (для небольших расфасовок и сохранения товара у потребителя), производственная и торговая упаковка. Особое внимание уделяется применяемым материалам, среди основных лидирующие позиции занимает пластик (30-40\%), бумага (30) и металл (в основном сталь и алюминий $)$ - 17-18\%. В то же время стекло остается самым экологически чистым и безопасным для здоровья населения упаковочным материалом. Полиэтиленовые пакеты характеризуются низкой себестоимостью, практичностью и считаются идеальной упаковкой.

К инновационным технологиям, оказывающим значительное влияние на развитие сферы упаковки плодоовощной продукции, нами отнесены следующие. Вопервых, упаковка РЕТ, отличительными характеристиками которой являются долговечность, износостойкость, малый вес, практичность, многократное использование, вторичная переработка, широкие возможности для дизайна. Недостаток материала связан с низкими барьерными свойствами, требующими особых условий хранения. Во-вторых, разработки «асtive» и «smart packaging», которые связаны с новыми технологически продвинутыми системами (микроэлектроника, компьютерные приложения, нанотехнологии), обеспечивающие более длительный срок хранения, контроль за свежестью, отображение информации о качестве, обеспечение безопасности и повышение удобства использования для потребителей. B-третьих, упаковочные тенденции SRP (от англ. Shelf-Ready Package), предусматривающие выкладывание товара на полку в транспортной таре, которая может быть легко вскрыта (например, по линиям перфорации), при этом сама транспортная тара брендирована для визуального выделения товара на полке. В 2018 г. Министерство антимонопольного регулирования и торговли Республики Беларусь предписало размещать овощи и фрукты в торговых залах в транспортной упаковке поставщика. Поэтому SRP-упаковка стала популярной и позволила экономить место в супермаркетах и время на выкладку товара (на $25 \%$ ), а также мотивировать покупателей, показывая продукцию полностью и в лучшем виде [4].

Анализ показал, что на продовольственном рынке товаропроизводителями и продавцами используется два вида полимерной упаковки: жесткая (контейнеры, флаконы, емкости) и гибкая (пленки, листы, и др.). При этом конкуренция между ними усиливается. Активное развитие получает гибкая упаковка за счет сокращения расходов на транспортировку, а также экономичности и удобства для потребителя. По данным Ассоциации гибкой упаковки, 83 \% брендов в настоящее время используют ту или иную гибкую упаковку. Кроме того, за последние пять лет $26 \%$ брендов увеличили ее внедрение, в то время как $31 \%$ намерены сделать это в ближайшее время. По оценке экспертов, к 2024 г. емкость глобального рынка гибкой упаковки превысит 250 млрд долл. США.

В качестве маркетингового приема используется и так называемая «антикризисная» упаковка, концепция которой стоит в уменьшении объема и веса продукта или размера упаковки при сохранении прежней цены. Эффективность такого подхода связана с проведением рекламной кампании, наиболее результативным видом которой является реклама в Интернете. Исследования, выполненные международной компанией Unilever, показали, что только 20 \% потребителей смогли увидеть различие между традиционной и «антикризисной» упаковками [2].

Важно понимать, что вне зависимости от тех или иных технологий основополагающими требованиями к упаковке плодоовощной продукции должны быть: безопасность, экологичность, надежность, совместимость, взаимозаменяемость, эстетичность, экономическая эффективность. Кроме того, практика показывает и необходимость применения дополнительных (требования логистики) и маркетинговых требований к упаковке плодоовощной продукции (информативность, эстетичность, узнаваемость, соответствие каналам сбыта, повышение 
ценности продукта). Данный аспект должен быть положен в основу товарной стратегии производителей и продавцов и базироваться на:

- разработке дизайна упаковки, учитывающего особенности продукта, требования потребителей целевого рынка, общую маркетинговую стратегию и фирменный стиль организации;

- определении размера, цвета, формы упаковки и выборе упаковочного материала;

- финансовой составляющей (абсолютная и относительная стоимость упаковки по отношению к самому товару).

В целом современные тенденции в упаковочной индустрии оказывают существенное влияние на конкурентоспособность плодоовощной продукции. При этом упаковочный материал включается в цену товара, а вид упаковки и ее функциональные свойства формируют качественные характеристики. На практике чем выше конечная цена товара, тем привлекательнее упаковка, которая влияет на его спрос и, следовательно, на коммерческий успех.

\section{Список использованных источников}

1. Академия рынка: маркетинг / А. Дайен [и др.] ; пер. с фр. - М. : Экономика, 1993. - 572 с.

2. Антикризисный маркетинг в упаковке [Электронный ресурс]. - Режим доступа: https://article.unipack.ru/ 24935/.- Дата доступа: 03.08.2020.

3. Власова, М. Л. Социологические методы в маркетинговых исследованиях / М. Л. Власова. - М. : Издательский дом ГУ ВШЭ, 2006. - 2006 с.

4. Гибкая упаковка: возможности и преимущества [Электронный ресурс]. - Режим доступа: https://cosmeticindustry.com/gibkaya-upakovka-vozmozhnosti-i-preimushhestva. html. - Дата доступа: 05.09.2020.

5. ГОСТ 17527-2003 [Электронный ресурс]. - Режим доступа: http://belotest.by/gost/001.055.020/gost-175272003/. - Дата доступа: 03.08.2020.
6. Гусаков, В. Г. Как обеспечить устойчивость и конкурентность национального АПК / В. Г. Гусаков // Вес. Нац. акад. навук Беларусі. Сер. аграр. навук. - 2013. № 1. - С. 9-22.

7. Дурович, А. П. Конкурентоспособность товаров в системе маркетинга: учеб. пособие / А. П. Дурович. Минск : БГЭУ, 1993. - 58 с.

8. Ильина, 3. М. Конкурентоспособность продукции и продовольственная безопасность. Теоретические и практические аспекты/3. М. Ильина, Н. Н. Батова. -Минск : Ин-т систем. исслед. в АПКНАНБеларуси, 2010. - 119 с.

9. Киреенко, Н. В. Маркетинговые инновации как важнейший элемент повышения эффективности товарной стратегии предприятия / Н. В. Киреенко // Проблемы экономики: сб. науч. тр. / Белорус. гос. с.-х. акад. ; редкол.: А. С. Журавский [и др.]. - Минск : Ин-т систем. исслед. в АПК НАНБеларуси, 2010. - Вып. 2 (11). - С. 54-66.

10. Киреенко, Н. Система мер по повышению эффективности сбыта сельскохозяйственной продукции и продовольствия в условиях развития интеграционных процессов / Н. Киреенко // Аграр. экон. - 2018. - № 3. - С. 31-41.

11. Пилипук, А. В. Конкурентоспособность предприятий пищевой промышленности Беларуси в условиях построения Евразийского экономического союза / А. В. Пилипук ; под ред. В. Г. Гусакова. - Минск : Ин-т систем. исслед. в АПК НАН Беларуси, 2018. - 237 с.

12. Пищевая упаковка: тенденции рынка [Электронный ресурс]. - Режим доступа: https://rosupack. unipack.ru/publication/70260/. - Дата доступа: 10.09.2020.

13. Селезнев, А. 3. Конкурентные позиции и инфраструктура рынка России / А. 3. Селезнев. - М. : Юристь, 1999. - 384 c.

14. Стариков, В. Я. Стратегический маркетинг. Политика товародвижения / В. Я. Стариков. - Минск : Издво МИУ, 2006. - 244 с.

15. Фатхутдинов, Р. А. Оценка конкурентоспособности страны / Р. А. Фатхутдтинов // Промышленность России. - 2000. - № 3. - С. 62-67.

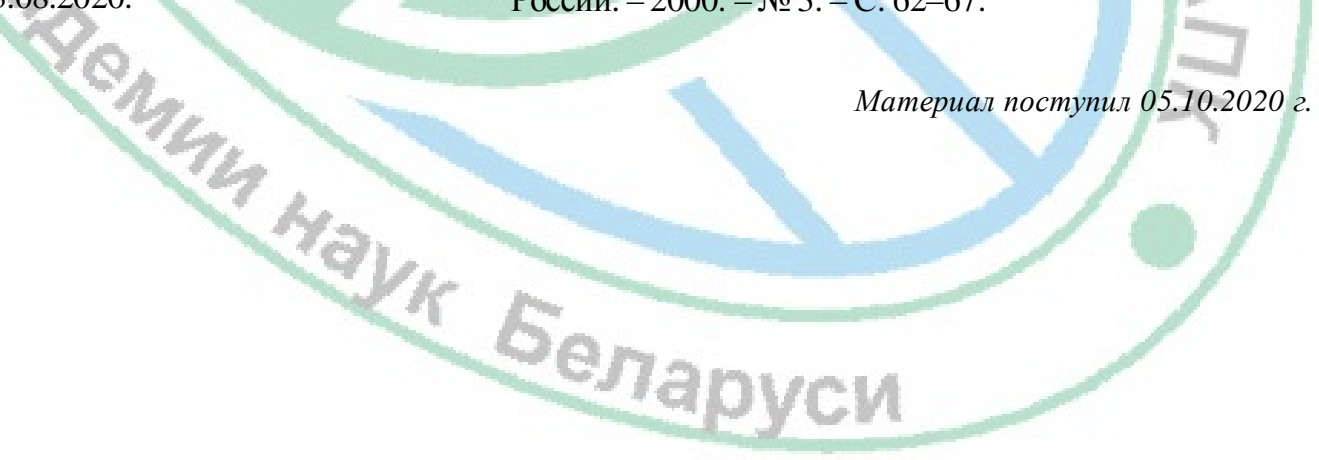

